Vol. 3, No. 2, Desember 2018, pISSN 2527-2853, eISSN 2549-2985

\title{
Rancang Bangun Otomasi Bangunan Untuk Meningkatkan Efisiensi Operasional Peralatan di Dalam Bangunannya
}

\author{
Mahendra Wardhana \\ Departemen Interior, Fakultas Arsitektur, Desain, dan Perencanaan, ITS Surabaya \\ Jl. Raya Keputih, Sukolilo - Surabaya 60119 Telp 031.5925223 \\ mahendra@interior.its.ac.id
}

\begin{abstract}
ABSTRAK
Perkembangan industri saat ini telah memasuki revolusi industri 4.0. Pada perkembangan ini setidaknya terdapat dua bagian penting yang berkembang sangat pesat yakni teknologi peralatan dan perkembangan internet. Dengan memanfaatkan dua perkembangan pesat tersebut, maka perangkat otomasi bangunan dapat optimal dirancang dan digunakan. Manfaat dari penggunaan perangkat otomasi bangunan ini juga sangat banyak dan sangat mendukung kebutuhan pengguna bangunannya.

Perangkat otomasi bangunan terdiri dari tiga bagian utama yakni sensor, relay dan unit kontrol sebagai pemberi perintah kepada relay yang diaktifkan atau sebaliknya. Ketiga bagian ini memiliki tugas sendiri-sendiri namun juga terintegrasi dalam sebuah pemrograman pada perangkat arduinonya. Sebagai hasilnya, perangkat ini akan berhasil membaca input dari sensornya apabila pemrograman yang dilakukan dijalankan dengan tepat oleh unit kontrolnya. Penggunaan internet sebagai pemberi perintah secara otomatis penuh ataupun dengan perintah manual menjadikan peralatan ini semakin mudah mendukung kebutuhan penggunanya karena dapat dioperasionalkan dari tempat yang jauh.
\end{abstract}

Kata kunci: otomasi; relay; kontrol; sensor

\section{ABSTRACT}

Today's industrial development has entered the 4.0 industrial revolution. In this development there are at least two important parts that are growing very rapidly, namely equipment technology and the development of the internet. By utilizing these two rapid developments, building automation devices can be optimally designed and used. The benefits of using this building automation device are also very much and very supportive of the needs of building users.

Building automation devices consist of three main parts, namely the sensor, relay and control unit as the command to the relay that is activated or vice versa. These three parts have their own assignments but are also integrated in a programming on an audio device. As a result, this device will succeed in reading the input from the sensor if the programming is carried out correctly by the control unit. The use of the internet as a giver of commands is fully automatic or with manual commands makes this equipment more easily support the needs of its users because it can be operated from a distance place.

Keywords: automation; relay; control; sensor

\section{PENDAHULUAN}

Otomasi bangunan pada akhir tahun 2018 menjadi sangat penting didiskusikan mengingat era ini telah ditandai dengan bangkitnya Industri 4.0. Kebangkitan era industri ini memiliki pengaruh kepada berbagai sisi kehidupan manusia. Kehadiran internet juga membantu mempercepat perkembangan serta informasi di semua sisi kehidupan. Demikian pula dengan perkembangan pada otomasi bangunan saat ini menjadi mulai bangkit dan berkembang. Pengembangan IT memegang kunci penting operasional suatu otomasi bangunan.

Perkembangan dunia otomasi bangunan saat ini telah memanfaatkan dua bagian penting yakni perkembangan industrialisasi di bidang peralatan bangunan, dan perkembangan informasi serta teknologi. Kedua bagian penting ini menjadi sangat perlu dipadukan untuk 
mendapatkan peralatan otomasi bangunan yang sempurna. Pemanfaatan IoT (Internet of Things) sangat memudahkan pengguna dalam mengoperasionalkan peralatan otomasi yang dipergunakannya.

Menurut sumber Gunagama dan Lathifa (2017) mengungkapkan bahwa di masa mendatang otomasi dalam pembangunan suatu bangunan akan memberikan dampak yang menguntungkan juga sebaliknya. Profesi perancang akan memiliki daya dukung juga sebaliknya dengan kehadran sistem otomasi yang juga pada proses desainnya. Ini menjadi diskusi lain yang memperkaya diskusi-diskusi tentang otomasi bangunan.

\section{A. Tantangan dan Peluang dalam Pengembangan Otomatisasi Bangunan}

Pengembangan otomasi bangunan memiliki beberapa tantangan dan peluang yang harus diperhatikan untuk mendapatkan hasil otomasi bangunan yang baik. Setidaknya terdapat dua tantangan yang ada. Tantangan pertama yakni bersumber dari kesiapan pengguna sedangkan tantangan kedua yakni penentuan (pemilihan) jenis otomasi yang sesuai untuk keperluan penggunanya. Pada peluang pengembangan otomasi bangunan, setidaknya ada dua peluang yang ada. Kedua peluang tersebut adalah kesiapan industri, dan kemajuan era IT saat ini.

Kesiapan pengguna menjadi tantangan dalam pengembangan otomasi bangunan, karena masih ada sebagian masyarakat yang mengalami kesulitan dalam penggunaan sarana kemajuan teknologi saat ini. Beberapa kesulitan tersebut dikarenakan di suatu daerah masih belum maju benar penguasaan teknologinya. Kesiapan pengguna ini dapat ditingkatkan dengan memajukan pengetahuan tentang teknologi dan informasi. Pola ini adalah semacam penyuluhan dan penjelasan kepada pengguna yang memerlukan penjelasan tentang operasional peralatan otomasi yang ada. Hal ini adalah juga disebabkan peralatan yang di desain kurang mudah dipahami operasionalnya dari tampilan desain. Petunjuk operasional perangkat menjadi penting untuk menjawab tantangan ini.

Jenis perangkat otomasi juga memberikan berbagai alternatif kegunaan dan pilihan yang ada. kegunaan ini menjadikan kekayaan pada manfaat dari perangkat otomasi ini. Namun demikian, tantangan yang tumbuh adalah pemilihan perangkat ini oleh penggunanya. Kesalahan pemilihan perangkat adalah faktor utama yang diperhatikan supaya tidak terjadi kesalahan dalam penggunaannya. Hal ini dapat diatasi dengan mengadakan demo penggunaan perangkat otomasi banguannya.

Kesiapan dari sisi industri adalah dikarenakan kemajuan dunia industri saat ini yang sudah berada pada tingkat 4.0. Industri telah banyak berkembang dan menyentuh berbagai kebutuhan serta kehidupan manusia. Kesiapan industri ini juga didukung oleh pendidikan tinggi yang menghasilkan SDM yang berkualitas tinggi yang sangat memadai saat ini.

Peluang kedua mengenai kemajuan IT saat ini menjadikan sarana internet mengambil bagian penting dalam pengendalian perangkat di dalam bangunan menjadi lebih berkembang pesat. Sarana ini terjawab dengan perkembangan IoT (Internet of Things) yang telah menjangkau berbagai wilayah di bumi ini. Pemanfaatan IoT ini mampu lebih menjadikan perangkat otomasi lebih mudah dioperasionalkan oleh pengguna dari tempat manapun.

\section{B. Permasalahan dalam Membangun Perangkat Otomasi Bangunan}

Permasalahan yang penting dalam otomasi ini adalah bagaimana menghasilkan perangkat otomasi bangunan yang mampu mengintegrasikan berbagai peralatan di dalam bangunan secara otomatis dan aman. Jawaban dari pertanyaan ini adalah akan dihasilkannya suatu peralatan otomasi bangunan yang canggih dan aman. Permasalahan di atas akan dijawab melalui tiga bagian perangkat otomasi yang masing-masing bagian menunjukkan fungsi yang berlainan namun mendukung satu dengan lainnya. Ketiga bagian tersebut adalah bagian 
pengangkap sensor, bagian pengolah data dan bagian yang memberikan perintah tertentu dari hasil pengolahan datanya.

\section{METODE PENELITIAN}

Metode dalam penelitian ini adalah menggunakan metode rancang bangun dan uji cobanya. Rancang bangun yang dilaksanakan adalah melalui rancangan perangkat otomasi bangunan terdiri dari tiga bagian besar dalam susunan kerjanya. Tiga bagian besar tersebut adalah web server, command center dan control unit. Ketiga bagian ini bekerjasama untuk menghasilkan peralatan otomasi yang lengkap dan utuh. Ketiga bagian tersebut memiliki fungsi dan tugas yang berlainan. Web server dan command center memiliki tugas dalam hal operasional perangkat otomasi bangunan. Sedangkan control unit memiliki tugas untuk memproses data dan menyediakan respon otomasi yang dijalankan. Rangkaian bagian di atas juga sesuai dengan pernyataan Pedro Domingues dan rekannya (2014) yang menyatakan bahwa terdapat setidaknya hardware dan software beserta rangkaian-rangkaiannya dalam perangkat otomasi bangunan ini.

Dalam perangkat unit kontrol terdapat tiga bagian utama. Ketiga bagian utama tersebut adalah bagian sensor, bagian pengolah data dan bagian channel-channel pengoperasionalannya. Masing-masing bagian merupakan satu rangkaian sirkuit yang berlainan. Namun demikian, ketiga sirkuit tersebut terhubungkan satu dengan lainnya sehingga dapat bekerja saling terkait sat dengan lainnya.

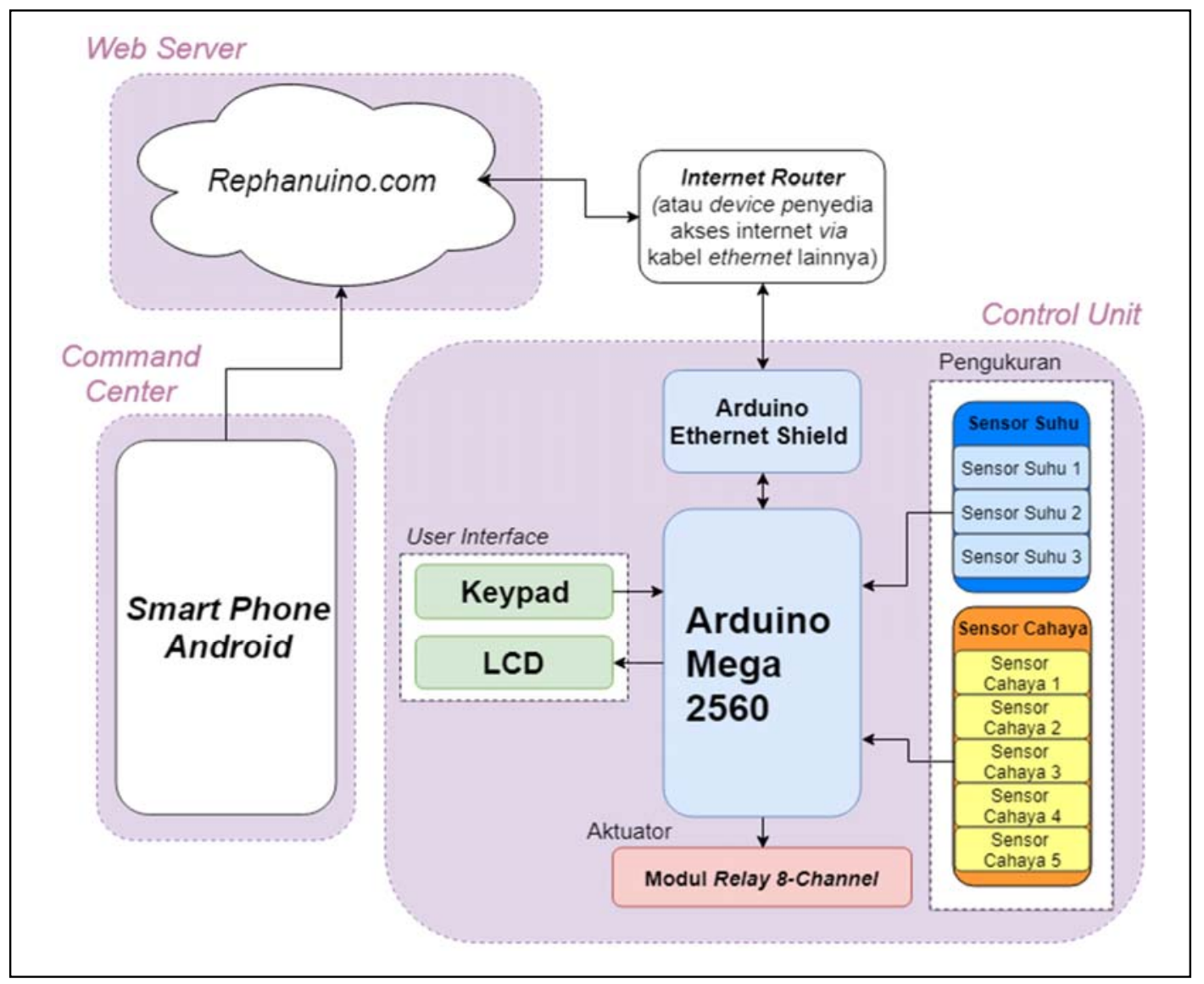

Gambar 1. Skema rangkaian kerja perangkat otomasi bangunan Sumber: Amstrabena (2018) 


\section{HASIL PENELITIAN DAN PEMBAHASAN}

Dalam perangkat ini sensor dirancang terdiri dari dua kelompok channel. Kelompok tersebut terdiri dari lima channel sensor cahaya dan dua channel suhu. Dua jenis sensor ini penting untuk ditanamkan dalam perangkat ini karena sistem otomasi bangunan mengambil data keadaan sekitar bangunan atau ruangnya. Data keadaan lingkungan ini adalah data cahaya dan suhu. Jadi, dua jenis sensor cahaya dan suhu sangat penting untuk direkam pada perangkat ini. Perekam sensor pada perangkat ini dinamakan sensor dock.

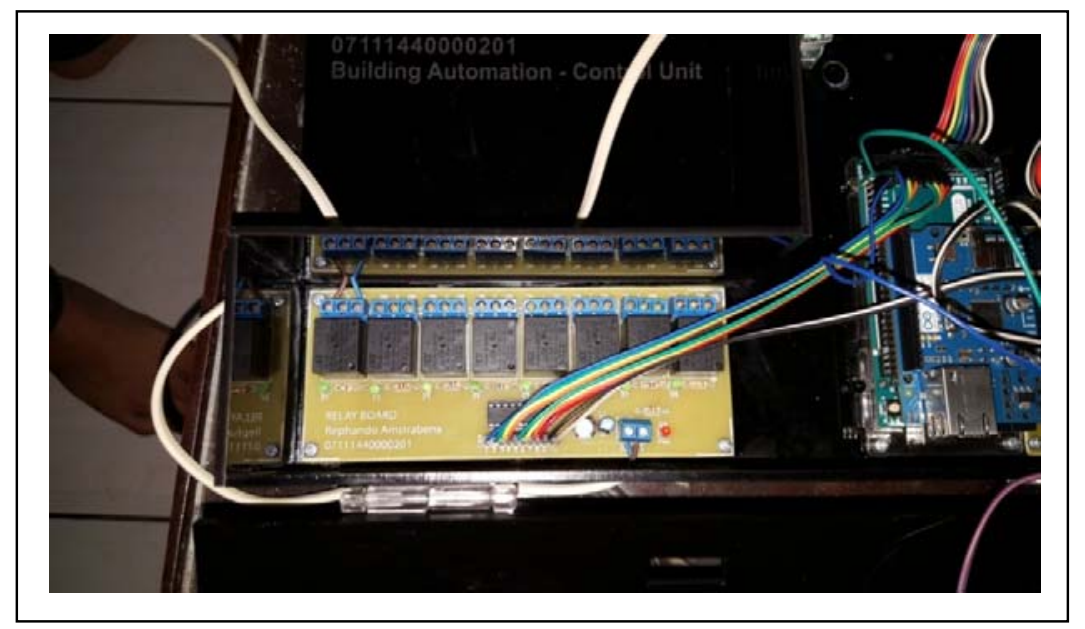

Gambar 2. Relay pada unot kontrol di perangkat otomasi bangunan Sumber: Dokumentasi Penulis (2018)

\section{A. Rancang Bangun Perangkat Otomasi Bangunan}

Pada unit kontrol di perangkat ini digunakan sistem relay. Pada perangkat ini terdapat delapan modul relay yang siap diaktifkan oleh program arduino. Pada perangkat relay ini modul relay berfungsi sebagai pengendali tegangannya. Dengan demikian, modul ini adalah modul pengolah dari data yang diterima sensor pada perangkat ini diolah menjadi perintah kepada modul relay ini. Perintah tersebut akan mengaktifkan relay atau sebaliknya.

Pada bagian lainnya dari perangkat ini adalah bagian pemrograman mode untuk beroperasinya relay yang ada pada perangkat ini. Pemrograman yang ada ditentukan oleh pin digital yang ada. Pin digital yang ada menunjukkan nilai high (tinggi) atau low (rendah). Penunjukan ukuran tinggi dan rendah tersebut ditentukan oleh input yang diprogramkan pada arduino di perangkat ini. Dengan demikian pada bagian ini akan terdapat setting untuk memasukkan nilai dan ukuran yang diinginkan serta reaksi relay yang diinginkan pula.

Bagian terakhir pada perangkat otomasi bangunan ini adalah bagian koneksi internet. Bagian ini bertujuan untuk pengendalian operasional perangkat melalui jaringan internet yang ada. Jaringan internet akan dimanfaatkan untuk mengoperasionalkan perangkat dari perangkat mobile (handphone). Operasional yang dapat dilakukan adalah memasukkan nilai kebutuhan tertentu untuk direspon oleh relay nantinya. Setting yang dapat diopersionalkan dari handphone adalah setting otomatis dan pengendalian secara manual (melalui handphone). 


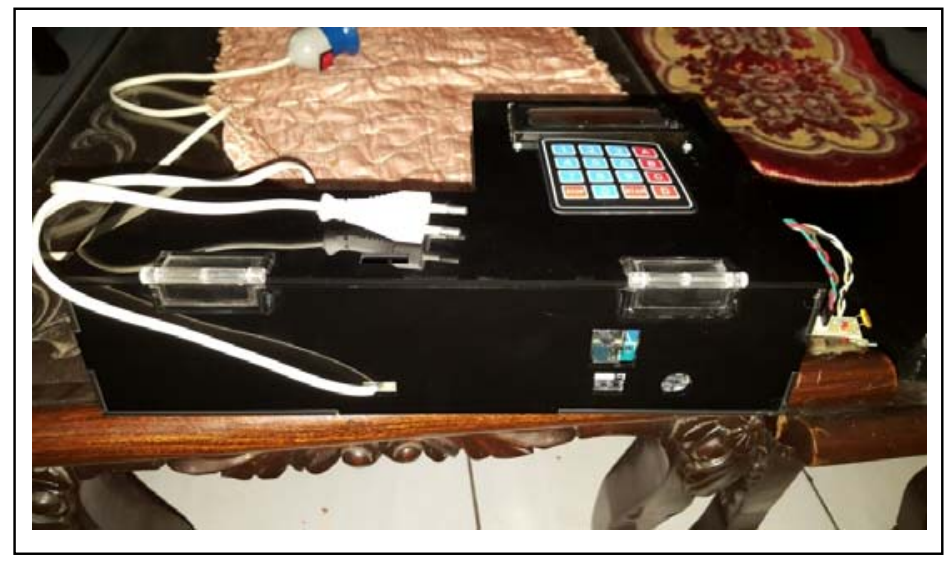

Gambar 3. Perangkat otomasi bangunan yag sudah siap diuji coba Sumber: Dokumentasi Penulis (2018)

Dengan demikian keamanan akan operasional perangkat ini akan terjamin dengan kemampuan pengendalian dari smartphone pengguna. Keamanan yang dimaksudkan adalah kemampuan pengambil alihan sistem operasional perangkat dari sistem pemrograman yang telah dilakukan. Tentu saja tidak hanya bila perangkat mengalami kegagalan dalam mengoperasionalkan channelnya, namun juga kemampuan untuk merubah respon channelnya dapat dilakukan dari kontrol manual ini. Pernyataan tentang kemungkinan adanya kegagalan dalam otomasi bangunan seperti uraian di atas juga dikuatkan oleh pernyataan German Osma dkk (2015) yang membicarakan tentang otomasi bangunan dalam hubungannya dengan optimalisasi energi pada bangunannya.

\section{B. Uji Coba Keberhasilan Perangkat}

Uji coba keberhasilan operasional peralatan ini ditentukan dari respon channel dalam menanggapi sensor dan perintah manual yang diberikan pengguna kepada perangkat otomasi bangunan ini. respon channel dalam mengaktifkan channel dari hasil pembacaan sensor dilakukan pada unit kontrol melalui perangkat arduino. Dengan demikian uji coba perangkat dilakukan dengan dua kegiatan penting yakni uji keberhasilkan pembacaan sensor dari respon sensor terhadap aksi channel serta uji coba keberhasilan perintah mengaktifkan channel secara manual melalui handphone yang telah disediakan.

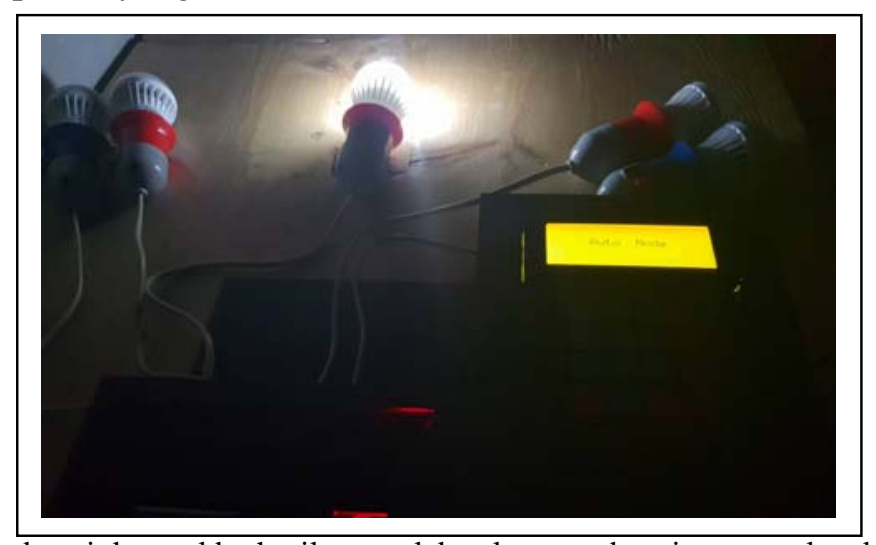

Gambar 4. Channel pada unit kontrol berhasil menyalakan lampu sebagai output relay dari sensor yang tidak menangkap cahaya

Sumber: Amstrabena (2018) 


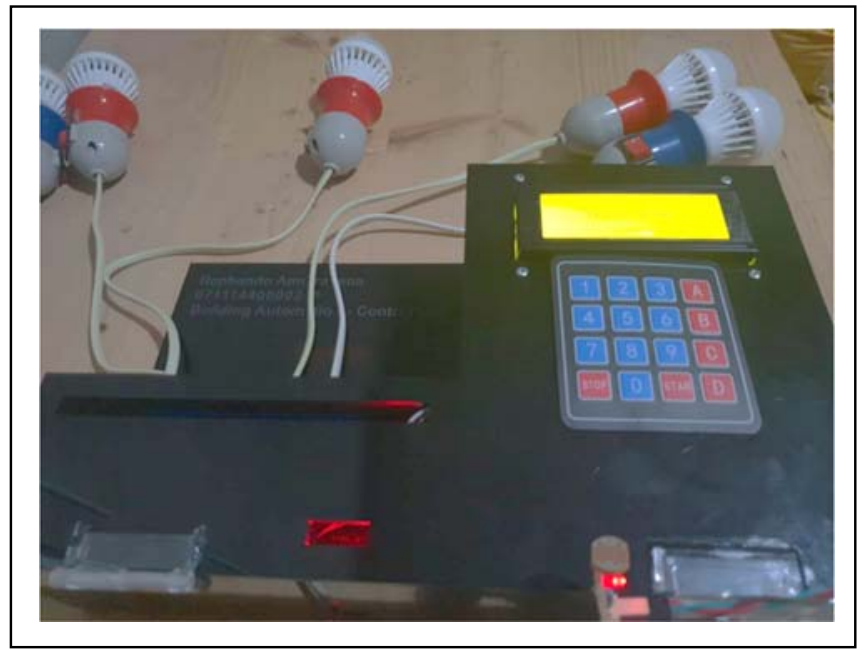

Gambar 5. Channel pada unit kontrol yang berhasil mematikan lampu sebagai output relay dari sensor yang menagkap adanya cahaya Sumber: Amstrabena (2018)

Dari uji coba yang dilakukan maka diperoleh kesimpulan bahwa unit kontrol mampu membaca sensor serta mampu merespon dengan mengaktifkan channel dengan baik. Perubahan data pada sensor cahaya dan suhu telah dapat dijalankan dengan baik oleh perangkat ini. Pada bagian lain, pembacaan dan respon oleh perintah manual pada perangkat otomasi ini juga berhasil dilakukan oleh perangkat ini. Perintah manual melalui penekanan channel yang diinginkan pada perangkat smartphone dapat dijalankan dengan baik oleh unit kontrol pada perangkat ini.

\section{KESIMPULAN}

Perangkat ini memiliki keunggulan sebagai pengatur operasional peralatan-peralatan di dalam bangunan secara otomatis. Sistem yang dibangun telah berhasil dijalankan oleh unit kontrol pada perangkat ini dengan baik. Peralatan-peralatan yang dapat dioperasionalkan secara otomatis melalui alat ini masih terbatas pada respon dalam mengaktifkan channelchannel relay yang ada, sehingga kebutuhan yang diprogramkan memiliki tingkat keaktifan tertentu dapat dijalankan dengan cara mengaktifkan relay secara bertingkat pula. Hal ini seperti analogi sensor tingkat tertentu akan mengaktifkan relay yang telah ditentukan pula.

Kegunaan dari perangkat otomasi bangunan ini sangat luas dan beragam. Manfaat utama dari keberadaan alat ini adalah untuk mengendalikan dana operasional yang tepat sesuai kebutuhan, pengaturan keadaan bangunan yang tepat sesuai kebutuhan dan aktivitas pengguna serta dukungan kepada keamanan bangunannya. Inilah manfaat utama dari kehadiran perangkat otomasi bangunan bagi penggunanya.

Mengingat pentingnya manfaat utama dalam penggunaan perangkat otomasi bangunannya, maka peningkatan kemampuan perangkat otomasi bangunan dapat ditingkatkan pada kegunaan yang lebih beragam lagi. Pendalaman kepada operasionalisasi perangkat memalui perintah suara, isyarat atau gerakan tertentu akan menjadikan kemampuan perangkat otomasi jauh lebih sempurna lagi. Intergasi dengan perangkat yang lebih beragam juga dapat dilakukan dengan meningkatkan kemampuan respon relay pada perangkat otomasi bangunan ini. Hal ini juga sejalan dengan pemikiran Valentina Fabi (2017) yang mengemukakan bahwa 
perkembangan kehidupan akan dapat dioptimalkan dengan kehadiran perangkat-perangkat otomasi bangunan seperti ini.

\section{DAFTAR PUSTAKA}

Amstrabena, Rephando. (2018). Rancang Bangun Modul Sistem Otomasi Bangunan Berbasis Konsep Internet of Things. Tugas Akhir DTE, Surabaya: ITS.

German Osmaa, Laura Amadoa, Rodolfo Villamizara, Gabriel Ordoñez. (2015). Building Automation Systems as Tool to Improve the Resilience from Energy Behaviour Approach. Procedia Engineering. Volume 115 Page 861-868.

Gunagama, M. Galih dan Lathifa, Nur Fitri. 2017. Automatictecture: Otomatisasi Penuh Dalam Arsitektur Masa Depan. Jurnal Arsitektur NALARs. Volume 16 Nomor 1 Januari 2017: 43-60.

Pedro Domingues, Paulo Carreira, Renato Vieira, Wolfgang Kastner. (2016). Building Automation Systems: Concepts and Technology Review. Computer Standards \& Interfaces. Volume 45 Maret Page 1-12.

Valentina Fabi, Verena M. Barthelmes, Marcel Schweiker, Stefano P. Corgnati. (2017). Insights into the Effects of Occupant Behaviour Lifestyles and Building Automation on Building Energy Use. Energy Procedia. Volume 140 Pege 48 - 56. 
Mahendra Wardhana

Rancang Bangun Otomasi Bangunan Untuk Meningkatkan Efisiensi Operasional Peralatan di Dalam Bangunannya 